\title{
Agronomic Suitability of Biologically Produced PARP as a Source of Phosphorus for Maize Production
}

\author{
Simfukwe Paul1 ${ }^{1}$, Bilima Tukuza Bester ${ }^{2}$ \\ ${ }^{1}$ School of Agriculture and Natural Resources, Mulungushi University, Kabwe, Zambia \\ ${ }^{2}$ Zambia Agricultural Research Institute, Chilanga, Zambia \\ Email:p_simfukwe@yahoo.com,psimfukwe@mu.ac.zm, favbless@gmail.com
}

How to cite this paper: Paul, S. and Bester, B.T. (2020) Agronomic Suitability of Biologically Produced PARP as a Source of Phosphorus for Maize Production. Agricultural Sciences, 11, 1033-1047. https://doi.org/10.4236/as.2020.1111067

Received: August 12, 2020

Accepted: November 13, 2020

Published: November 16, 2020

Copyright $\odot 2020$ by author(s) and Scientific Research Publishing Inc. This work is licensed under the Creative Commons Attribution International License (CC BY 4.0).

http://creativecommons.org/licenses/by/4.0/

\begin{abstract}
Phosphorus $(\mathrm{P})$ and Nitrogen $(\mathrm{N})$ deficiencies are recognized as the major constraint of agricultural productivity in developing countries including Zambia. While $\mathrm{N}$ deficits can be restored at least in part through the application of crop residues and manure, the restoration of soil $\mathrm{P}$ can only be achieved by use of phosphate fertilizers which are unaffordable by the small scale farmers. The aim of the study was to assess the availability of $P$ for crop use from rock phosphate (RP), partially acidulated by acid produced by sulfur oxidizing bacteria. The RP was obtained from Keren Mining Limited at Sinda district, Zambia; the Pyrite rock (iron sulfur) and bacteria culture were obtained Nampundwe mine dump. The pyrite and PR were ground and mixed with the bacterial culture to produce the Partially Acidulated Rock Phosphate (PARP). A pot experiment was set up in a CRB design in a greenhouse on four soil types with four treatments of: soil alone (control), soil with GRP, soil with PARP and soil with super single phosphate (SSP) replicated four times. The results showed that the plant height, biomass yield and $\mathrm{P}$ uptake across the different $P$ sources showed significant differences $(p<0.01)$; particularly, the PARP and SSP were significantly higher than the both control and the GRP. A comparison of PARP and SSP within each soil based on both biomass yield and $P$ uptake showed no significant difference between them. Despite the fact that the RAE values based on biomass yield were in most cases higher than those base on the $\mathrm{P}$ uptake, the trend was the same. On average the PARP was $>90 \%$ effective within and across the four soils indicating that the PARP is reactive and suitable for direct application for crop production.
\end{abstract}

\section{Keywords}

Rock Phosphate, Pyrite, Partial Acidulated Rock Phosphate, Agronomic Effectiveness 


\section{Introduction}

Most soils in Zambia are inherently low in P (3 - $12 \mathrm{ppm})$ [1] and this seriously limits the productivity of maize which is the staple food crop. This deficiency is more severe in the high rainfall $(800-1200 \mathrm{~mm}$ ) regions of the country (Region III) where predominant soils are the highly weathered Oxisols and Ultisols with high phosphorous fixing capacities [2]. Although judicious application of inorganic P fertilizers is recognized as the most effective method for alleviating P deficiencies, their high cost and inaccessibility limit their use to the majority of Zambia farmers, particularly the smallholder farms [3]. Application of farm yard manures and crop residues does add some limited quantities at farm level [4] [5] due to their low $\mathrm{P}$ content. For this reason, organic matter has been used mainly as sources of $\mathrm{N}$, while inorganic fertilizers are used to supply $\mathrm{P}$.

Zambia is endowed with a number of rock phosphate (RP) deposits of igneous origin that are associated with syenite and carbonatite related deposition. Syenite related RP deposits are found at Chilembwe in Eastern province and Mumbwa North, Central province. Carbonatite related RP deposits are found at Kaluwe, Rufunsa in Lusaka province, and at Nkombwa Hill in Northern Province [6]. Out of the four RP deposits, only two (Chilembwe and Mumbwa) hold promise of their exploitation for agricultural use [7]. The Chilembwe deposit constitutes four ore bodies associated with syenites varying in composition from mica syenites to monozonites, with the apatite rock in the form of massive lenses comprising apaptite, quartz, alkali feldspars, mica and amphibole with the $\mathrm{P}$ content varying $10 \%-12 \% \mathrm{P}_{2} \mathrm{O}_{5}$ estimated at 1.8 million tones [6] [8]. The Mumbwa North phosphate is associated with apatite and it is estimated at $1 \mathrm{Mt}$ with the grade between $8 \%-12 \%$ [9]. The Nkombwa Hill RP deposits have the grade of $4.5 \% \mathrm{P}_{2} \mathrm{O}_{5}$, but most of the phosphorus occurs as isokite $\left(\mathrm{CaMg}\left(\mathrm{PO}_{4}\right)\right)$ though beneficial for agricultural purposes, there is no effective beneficiation technology that exists [8]. The Kaluwe PR $0.5 \%-8.5 \% \mathrm{P}_{2} \mathrm{O}_{5}$ grade but the Niobium in these PRs as pyrochlore makes it technically and economically not suitable for phosphate extraction for agricultural purposes [10] [11].

Studies show that the agronomic effectiveness of direct application of indigenous ground rock phosphate (GRP) and its derivatives on major crops and representative soils is generally inferior to triple superphosphate (TSP) and single superphosphate (SSP), largely owing to the low solubility of RP of igneous origin [12]. Depending on soil and climate, it could take up to 4 years of annual application before rock phosphate treatments become as effective as super phosphate [13]. One method of reducing this long lag phase is to increase the solubility of rock phosphate by treating it with small amount of sulfuric acid or phosphoric acids. Such products, commonly known as partially acidulated rock phosphate (PARP), have not shown lag effects and have given high agronomic effectiveness [11]. Partial acidulation can be effected by industrial processing but this approach is capital intensive [14]. A possible alternative and probably less 
expensive [3] [15] means of producing PARP is the use of Chemolithoautotrophic bacteria to oxidize pyrite which in turn produces sulfuric acid that can be used to acidulate the rock phosphate [16] [17]. The use of partially acidulated rock phosphate by chemolithotrophic bacteria to improve available $\mathrm{P}$ in the soil will be a sustainable management of soil chemical and physical properties in such fragile ecological zone [16]. The long term effect of partially acidulated rock phosphate application would in general be an improvement to available $\mathrm{P}$ in the soil that would facilitate continuous farm land utilization as opposed to use of SSP fertilizer as a source of available $\mathrm{P}$ which is very expensive for small holder farmers to use [3] [15]. The main aim of this research was to determine agronomic suitability of biologically produced PARP as a source of phosphorus for maize in comparison to SSP fertilizer by: 1) determining the effectiveness of the oxidizing bacteria culture for PARP production from the local rock phosphate and 2) Comparing the $P$ uptake by the maize among the biologically produced PARP, SSP fertilizer and Ground Rock Phosphate when are used as source of phosphorus.

\section{Materials and Methods}

\subsection{The Soil for the Experiments}

Soils used in this study were obtained from Mansa, Kasama, Mporokoso and Mufulira all located in Region III of Zambia's Agro-ecological Zone with a wet season from November to April and dry season from May to October. The soils were highly varied and were classified using the World Reference Base for soil resources 2006 edition: Mansa: ferric Acrisols, well drained sandy clay loam to sandy clay texture; Kasama at Misamfu Research station: Haplic Ferralsols well drained, deep, highly leached, acidic, sandy clay loam with a sandy loam top soil, developed on the quartzitic sandstone is overlain by unconsolidated schistose formations; At Mporokoso soils were classified as Rhodic Ferrasol, well drained and deep, clayey soils develop from developed on the quartzitic sandstone; at Mufulira Research station soils were-Haplic Acrisol, (Chromic), highly leached, acidic sandy loams and clay illuviation, developed from Schist parent material. See location of the sites (Table 1).

The experiment was conducted at Zambia Agriculture Research Institute (ZARI), Mount Makulu Research Station, Chilanga in the greenhouse, located at Latitude 150.550 'S, Longitude 280.250 'E and 1213 meters above sea level.

Table 1. Geographical location and altitude of the sites selected for the study.

\begin{tabular}{cccc}
\hline Site & Location & Altitude (M) & Rainfall/Yr \\
\hline Kasama (Misamfu Research station) & E 31 $10^{\prime}$; S $10^{\circ} 10^{\prime}$ & $1380 \mathrm{~m}$ & $>1000 \mathrm{~mm}$ \\
Mansa (Mansa Research Station) & E 28 $53^{\prime}$; S $11^{\circ} 11^{\prime}$ & $1216 \mathrm{~m}$ & $>1000 \mathrm{~mm}$ \\
Mulfuria (Mufulira Research Station) & E 28 $14^{\prime}$; S $12^{\circ} 31^{\prime}$ & $8075 \mathrm{~m}$ & $>1000 \mathrm{~mm}$ \\
Mporokoso & E 30 $07^{\prime} ; \mathrm{S} 09^{\circ} 22^{\prime}$ & $1384 \mathrm{~m}$ & $>1000 \mathrm{~mm}$ \\
\hline
\end{tabular}


A Completely Randomized Design (CRD) experiment was laid out in the greenhouse and the duration of the experiment was about 21 weeks. The experiment was in two phases: The first phase of the experiment was the Laboratory culturing of sulfur oxidizing bacteria for a week, 6 weeks incubation of pyrite to produce acid and 6 weeks solubilization of rock phosphates to produce PARP. The second phase comprised pot experiments where the four soils were mixed with the different treatments and seven weeks of observation and measurement in the greenhouse.

The rock phosphate was obtained from: 1) Petauke at Chilembwe Hill, 2) Sinda at the Mine owned by Keren Mining Limited, 3) Mumbwa at Sugar Loaf Mountain, and 4) Petauke at Chilembwe Hill. The pyrite and the sulfur oxidizing bacteria were obtained from Nampundwe Mine. The bacteria were collected from the water samples and sludge along the drainage ditches near the mine. These served as a source of inoculums for the bacteria which was used in the experiments to oxidize pyrite to sulfuric acid.

\subsection{Preparation of Solid Ferrous Iron-Silica Gel Medium}

The Ferrous iron- silica gel medium was prepared according to [18]. To obtain a ferrous iron-silica gel the following salts were dissolved together in $250 \mathrm{ml}$ of distilled water a flask; $6.00 \mathrm{~g}\left(\mathrm{NH}_{4}\right)_{2} \mathrm{SO}_{4}, 0.05 \mathrm{~g} \mathrm{KCL}, 0.50 \mathrm{~g} \mathrm{MgSO}_{4} \cdot 7 \mathrm{H}_{2} \mathrm{O}$, and $0.01 \mathrm{~g} \mathrm{Ca}\left(\mathrm{NO}_{3}\right)_{2}$. The resultant solution hereafter was referred to as solution $\mathrm{A}$ was dispensed in $25 \mathrm{ml}$ aliquots sterilized for 15 minutes at $1210^{\circ} \mathrm{C}$. Solution $\mathrm{B}$ was made of $44.22 \mathrm{~g} \mathrm{FeSO} \cdot 7 \mathrm{H}_{2} \mathrm{O}$ in $290 \mathrm{ml}$ distilled water acidified with $10 \mathrm{ml}$ of $1 \mathrm{~N} \mathrm{H}_{2} \mathrm{SO}_{4}$. A buffer solution of $13.5 \mathrm{~g} \mathrm{~K}_{2} \mathrm{HPO}_{4}$ in $100 \mathrm{ml}$ of sterilized distilled water. Sterilized silicic acid was distributed in $75 \mathrm{ml}$ quantities. The solid medium was made by aseptically adding, $1 \mathrm{ml}$ of solution B to $75 \mathrm{ml}$ of sterile silicic acid, and $1 \mathrm{ml}$ of the buffer solution to $25 \mathrm{ml}$ of sterile solution A. The resulting two solutions were mixed to form the silica gel medium.

The $9 \mathrm{~K}$ medium of Silverman and Lundgren solution was used in multiplying

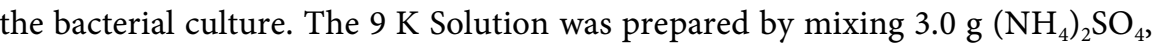
$0.1 \mathrm{~g} \mathrm{KCL}, 0.5 \mathrm{~g} \mathrm{~K}_{2} \mathrm{HPO}_{4}, 0.5 \mathrm{~g} \mathrm{MgSO}_{4} \cdot 7 \mathrm{H}_{2} \mathrm{O}$ and $0.01 \mathrm{~g} \mathrm{Ca}\left(\mathrm{NO}_{3}\right)_{2}$ in $700 \mathrm{ml}$ of distilled water in a $1 \mathrm{~L}$ flask according to [19]. $100 \mathrm{mls}$ of $9 \mathrm{~K}$ solution and solution B from above were sterilized separately and mixed in $250 \mathrm{ml}$ Erlenmeyer flasks making the $9 \mathrm{~K}$ medium of Silverman and Lundgren.

\subsection{Culturing of the Bacteria}

The water samples collected from Nampundwe Mine was used in the culturing of the bacteria using the [20] method. The sulfur oxidizing bacteria was identified as a gram positive, rod shaped, smooth, making concentric and white colour colonies, classified to bacilli of Thiobacillus thiooxidans. A pure culture was obtained by planting and replanting on ferrous iron silica gel every three days, over a fifteen day period. The culture was then multiplied and maintained at room temperature in $250 \mathrm{ml}$ Erlenmeyer flasks containing $100 \mathrm{ml}$ of $9 \mathrm{~K}$ medium of 
Silverman and Lundgren. The bacteria was multiplied by scrapping a sterile loop on a pure culture which was growing on the solid medium in a slant tube. A sterile needle and syringe was used to draw up the bacterial suspension and inoculate a previously autoclaved and cooled fermenter unit containing the liquid medium. The fermenter was connected to an electromagnetic air pump and filter so that there is constant supply of oxygen and also agitation of the medium. The fermenter unit was left for a period of 3 to 4 days by which time the bacteria had multiplied adequately.

\subsection{Incubation of Pyrite and Solubilization of the Rock Phosphate}

To oxidize the pyrite using sulphur oxidizing bacteria according to [21], $100 \mathrm{~g}$ of ground pyrite was placed into $50 \mathrm{ml}$ capacity beakers. The bacteria culture prepared from the preceding phase was diluted five-fold. Appropriate amounts of these dilute solutions were added to the pyrite to bring the moisture content to 21 percent by weight and kept $30^{\circ} \mathrm{C}$ in the darkness for six weeks. Five samples from each treatment were randomly selected every week for analysis of $\mathrm{pH}$ and total acidity over a period of six weeks. The $\mathrm{FeS}_{2}+$ bacterial culture + nutrient solution produced the strongest acidity among the three combinations (see Table 2). To determine the $\mathrm{pH}, 10 \mathrm{~g}$ of sample was mixed with $50 \mathrm{ml}$ of distilled water, the suspension shaken for an hour after which the $\mathrm{pH}$ of the suspension was measured using a digital $\mathrm{pH}$ meter. The total acidity of the sample was determined on a $25 \mathrm{ml}$ aliquot filtrate of the suspension by titration with $0.1 \mathrm{~N}$ $\mathrm{NaOH}$.

The four rock phosphates above were evaluated for water soluble P. The rock phosphate from Sinda was selected for the production of PARP in this experiment because it produced the highest water soluble $\mathrm{P}$ content under the treatment of $\mathrm{FeS}_{2}+$ bacterial culture + Nutrient Solution (Table 2). The bulk samples of the selected rock phosphate were crushed and ground to produce Ground Rock Phosphate (GRP). Portions of GRPs were treated with the acid produced from the above procedure to produce the Partially Acidulated Rock Phosphate (PARP) which was used as a source of $\mathrm{P}$ for maize in the pot experiment. Every week, five beakers from each treatment were removed and analysed for water-soluble $\mathrm{P}$. The water soluble $\mathrm{P}$, was determined from $1 \mathrm{~g}$ moist sample extracted with $100 \mathrm{mls}$ distilled water, shaken for $30 \mathrm{~min}$ and filtered. The concentrations of water soluble P in the filtrate was measured by UV/Visible Spectroscopy as described by [22].

Table 2. Treatment combination for incubation of pyrite.

\begin{tabular}{ccc}
\hline $\begin{array}{c}\text { Treat. } \\
\text { No. }\end{array}$ & Composition & Additives to Pyrite \\
\hline 1 & $\mathrm{FeS}_{2}$ & Distilled Water \\
2 & $\mathrm{FeS}_{2}+$ bacterial culture & Microbial Culture \\
3 & $\mathrm{FeS}_{2}+$ bacterial culture + nutrient Solution & Microbial Culture and Nutrient Solution \\
\hline
\end{tabular}




\subsection{Greenhouse Experiment}

The soils described above were used and were characterized by low $\mathrm{pH}$ and $\mathrm{P}$ content, as observed in Table 3. The soils were composite samples from 0 - 20 $\mathrm{cm}$ soil depth in each soil.

A pot experiment to test the agronomic effectiveness of the PARP produced from the above experiments as a source of $\mathrm{P}$ for maize was conducted under greenhouse conditions. The treatments consisted four sources of $\mathrm{P}$, namely: 1) the control (soil in without any additions), 2) soils treated with Ground Rock Phosphate (GPR), 3) soils treated with the Partially Acidulated Rock Phosphate (PARP) and 4) soils treated with Single Super Phosphate (SSP) fertilizer. The phosphate rock used was obtained from Keren Mining Limited at Sinda district. PARP, GRP and SSP fertilizer were applied at rates equivalent to $40 \mathrm{~kg}(\cong 0.9 \mathrm{~g}$ $\mathrm{P}_{2} \mathrm{O}_{5}$ per plant) $\mathrm{P}_{2} \mathrm{O}_{5}$ per hectare from each source of $\mathrm{P}$. Uniform applications rates of $20 \mathrm{~kg} / \mathrm{Ha}(\cong 0.45 \mathrm{~g}$ per plant) of Nitrogen $(\mathrm{N})$ and Potassium $(\mathrm{K})$ using Urea $(46 \% \mathrm{~N})$ and Muriate of potash $\left(62 \% \mathrm{~K}_{2} \mathrm{O}\right)$. Each treatment had 4 replicates, giving a total of 64 experimental units (4 sources of $\mathrm{P}, 4$ soils, 4 replicates), see Table 4.

\subsection{Setting Up of the Pot Experiment}

Amounts of SSP or PAPR, GRP to give $300 \mathrm{mg} \mathrm{P} \mathrm{kg}^{-1}(0.9 \mathrm{~g})$ soil were weighed out and mix thoroughly with three (3) $\mathrm{kg}$ of air dried soil placed in plastic pots. The amounts of $\mathrm{P}$ added were calculated on the basis of total $\mathrm{P}$ content of each $\mathrm{P}$ source. Uniform levels of urea, $\mathrm{KCl}$ were added to all pots to supply $150 \mathrm{mg} \mathrm{N}$ $\mathrm{kg}^{-1}(0.45 \mathrm{~g})$ soil, including the no-P control treatment. The pots were arranged in a randomized block design with 3 replications in the greenhouse. The pots were sown with presoaked seeds of the indicator crop (Zea mays L.) at a rate of

Table 3. Some soil chemical properties of the four soils.

\begin{tabular}{cccccccc}
\hline Soil sites & $\begin{array}{c}\mathrm{pH} \\
\left(\mathrm{CaCl}_{2}\right)\end{array}$ & $\begin{array}{c}\mathrm{P} \\
(\mathrm{ppm})\end{array}$ & $\begin{array}{c}\mathrm{N} \\
(\%)\end{array}$ & $\begin{array}{c}\mathrm{Fe} \\
(\mathrm{ppm})\end{array}$ & $\begin{array}{c}\mathrm{Ca} \\
(\mathrm{ppm})\end{array}$ & $\begin{array}{c}\mathrm{OC} \\
(\%)\end{array}$ & $\begin{array}{c}\mathrm{CEC} \\
(\mathrm{cmol} / \mathrm{kg})\end{array}$ \\
\hline Kasama & 4.2 & 2 & 0.02 & 57 & 2040 & 1.02 & 4.34 \\
Mansa & 4.3 & 2 & 0.02 & 66 & 2010 & 0.07 & 2.97 \\
Mulfuria & 4.5 & 3 & 0.03 & 78 & 2030 & 0.64 & 4.32 \\
Mporokoso & 4.2 & 3 & 0.03 & 59 & 2020 & 1.19 & 4.56
\end{tabular}

Table 4. Description of the treatments used in the study.

\begin{tabular}{cr}
\hline Treatment & Description of treatment in all the four different soils \\
\hline Control & Soil alone ( $3 \mathrm{~kg}$ soil, $0.45 \mathrm{~g}$ urea, $0.45 \mathrm{~g}$ Muriate of potash) \\
Soil + GRP & $3 \mathrm{~kg}$ soil mixed with GRP, $0.45 \mathrm{~g}$ urea, $0.45 \mathrm{~g}$ Muriate of potash \\
Soil + PARP & $3 \mathrm{~kg}$ soil mixed with PARP, $0.45 \mathrm{~g}$ urea, $0.45 \mathrm{~g}$ Muriate of potash \\
Soil + SSP & $3 \mathrm{~kg}$ soil, $0.9 \mathrm{~g} \mathrm{SSP}, 0.45 \mathrm{~g}$ urea, $0.45 \mathrm{~g}$ Muriate of potash \\
\hline
\end{tabular}


four seeds per pot and thinned to one plants per pot after germination. The pots were watered as required to maintain soil moisture at about $70 \%$ of field capacity. The plants were grown for a total of seven weeks after which the above-ground portion was harvested. Harvesting, was done by cutting the shoot close to the soil surface, chopped into smaller pieces and oven dried at $700^{\circ} \mathrm{C}$ until it attains constant weight, called the above ground dry matter yield (DMY) or the biomass yield. Using DMY, the Relative Agronomic Effectiveness (RAE) of PARP as a source of $\mathrm{P}$ for maize relative to SSP was determined as follows:

$\mathrm{RAEb}=[(\mathrm{DMY}$ treatment $-\mathrm{DMY}$ control $) /($ DMY SSP - DMY control $)] \times 100$

RAEPut $=[(\mathrm{P}$ uptake treatment $-\mathrm{P}$ uptake control $) /(\mathrm{P}$ uptake SSP $-\mathrm{P}$ uptake control) $] \times 100$

\subsection{Determination of $P$ Uptake by the Crop and Other Agronomic Parameters}

Plant tissue analysis was used to determine P uptake. The P content of maize dry matter was determined from $1 \mathrm{~g}$ dry ground plant material using the dry ashing method described by [23]. The $1 \mathrm{~g}$ of dried ground plant material was boiled in $1 \%$ nitric acid, ignited and cooled. The residue dissolved in $20 \mathrm{ml} 1 \mathrm{~N}$ nitric acid. The solution was heated for 20 minutes on a hot plate, cooled, filtered and diluted to $100 \mathrm{ml}$. One milliliter of sample was used to develop color and P determined calorimetrically on a Spectrophotometer at $882 \mathrm{~nm}$. Agronomic parameters of Plant height, the number of leaves, leaves with typical symptoms of $\mathrm{p}$ deficiency (purple appearance on the edges of the leaves), were measured weekly from the date of thinning to the date of harvest.

\subsection{Data Analysis}

Analysis of variance (ANOVA) was performed to determined significant differences in DM yield and P uptake between the various treatments. The ANOVA was based on factorial arrangement in a randomized complete block design in which the effects of replication, $P$ source were accounted for as sources of variance using the Genstat discovery Edition computer software.

\section{Results}

\subsection{The Effectiveness of the Oxidizing Bacteria Culture for PARP Production}

The result of the experiment for incubation of pyrite and bacteria culture are presented in the table and Figure 1. Figure 1 shows the $\mathrm{pH}$ values obtained from the treatments over the period of six weeks.

The results in the table shows the $\mathrm{pH}$ values obtained from the treatments of the pyrite incubation. The combination treatment of $\mathrm{FeS}_{2}+$ Bacterial culture + Nutrient solution produced the highest acidity, $\mathrm{pH}=2.3$ (which is closer to the $\mathrm{pH}$ of sulfuric acid) compared to 3.6 and 4.3 in $\mathrm{FeS}_{2}+$ bacterial culture and $\mathrm{FeS}_{2}$ respectively at the end of 6 weeks period. 


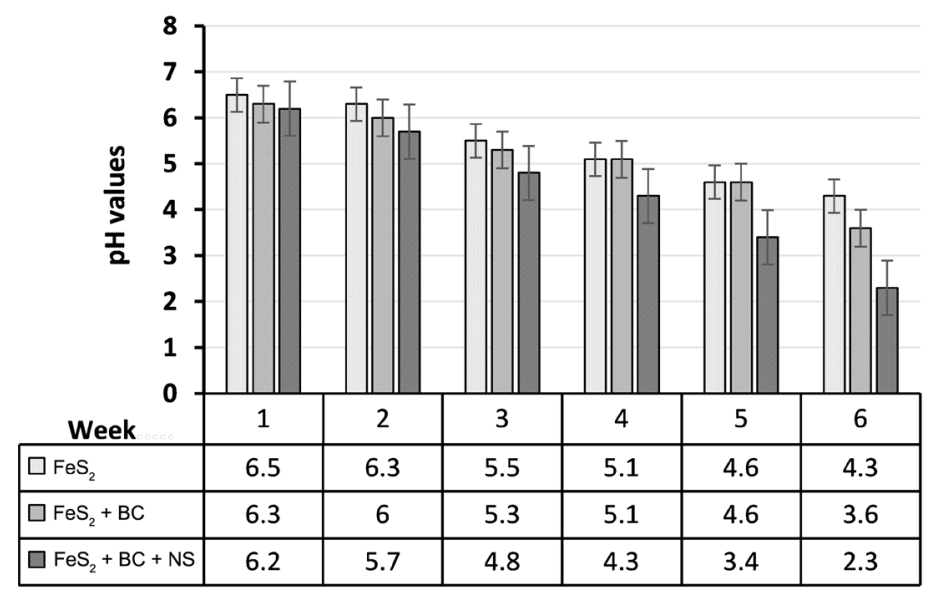

Figure 1. Showing $\mathrm{pH}$ values of pyrite and bacteria culture over the period of 6 weeks.

\subsection{Comparing the Plant Height, $P$ Uptake and Biomass Yield among the GPR, PARP and SSP Fertilizer Treatments When Used as Source of Phosphorus}

The analysis of plant height, biomass yield and $\mathrm{P}$ uptake across the different $\mathrm{P}$ sources showed significant differences $(\mathrm{p}<0.01)$ among them. Particularly, the differences were observed between the control and all other treatments except for the GRP treatment. The average level of $\mathrm{P}$ uptake in the soils treated with both PARP and SSP was significantly higher $(\mathrm{p}<0.01)$ than the soils treated with both GRP and the control. A comparison of PARP and SSP within a soil based on both biomass yield and P uptake showed that the effect of PARP input was comparable to that of SSP input. The biomass yield under the PARP treatment ranged between $47.7 \mathrm{~g}$ in Kasama soil to $48.9 \mathrm{~g}$ in Mprokoso soils, while in the SSP treatment, it ranged between 48.1g in Mufulira soil to $49.1 \mathrm{~g}$ in Mporokoso soils, showing no significant differences $(\mathrm{p}>0.05)$ between PARP and SSP regardless of the soil. Similarly the P uptake under the PARP ranged from 0.40 in Kasama soils to 28 in Mporokoso soil while in the SSP treatments it ranged 0.40 in Kasama soil to 0.33 in Mprokoso soil. The biologically produced PARP was as good as SSP as there was no significant different $(p>0.05)$ between them within the soil as can be seen from the letters showing the differences in Table 5 and Figure 2(b) and Figure 2(c).

A comparison of soils $\mathrm{P}$ uptake among the soils show that there was more $\mathrm{P}$ uptake in the Kasama soils than all other soils. The P uptake in Kasama soil ( $\mathrm{p}=$ $0.40 \% \mathrm{P}$, highest) was $30 \%$ higher than the $\mathrm{P}$ uptake in Mporokoso soil ( $\mathrm{p}=$ $0.28 \%$, the lowest) in the PARP treatment while in the SSP treatment, the P uptake was $17.5 \%$ higher in Kasama soil $(\mathrm{p}=0.40 \%)$ compared to Mporokoso soil $(\mathrm{p}=0.33 \%)$. Similarly the plant height followed a similar tend while the plant biomass yield did not show a significant difference among the soils types see Table 5 and Figures 2(a)-(c). Irrespective of the soil, the application of PARP increased the production of biomass yield in relation to the control and the GRP treatments. 


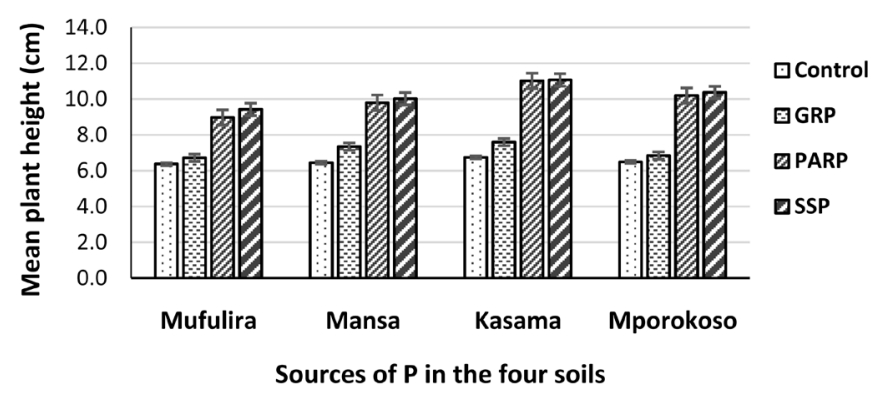

(a)

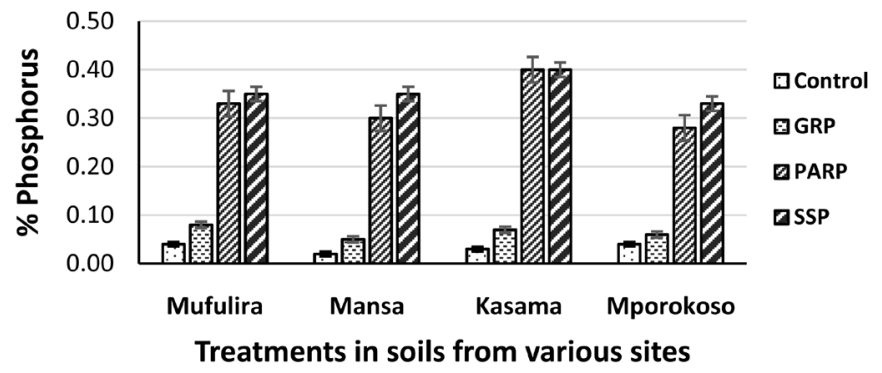

(b)

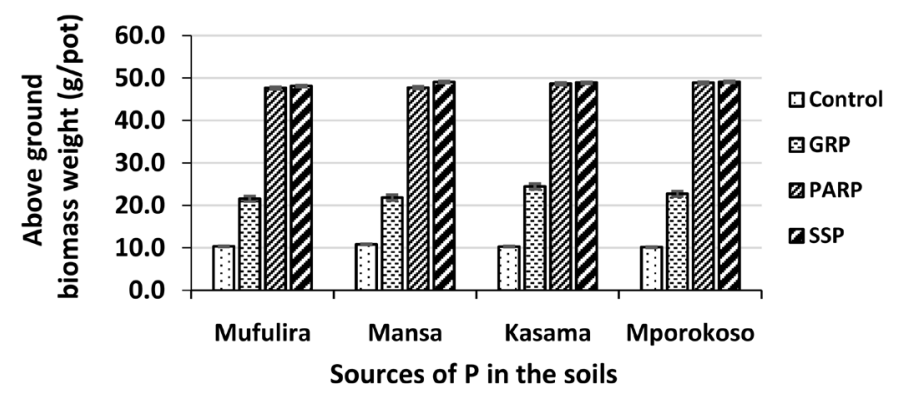

(c)

Figure 2. Shows the mean plant height (a), \% P uptake (b) and the biomass yield (c) of maize at 7 weeks in the Mufulira, Mansa, Kasama and Mporokoso soils. (a) Mean plant height in the four sources of $\mathrm{P}$ in the four soil; (b) Percentage phosphorus uptake in various treatments in the four soils; (c) Above ground biomss weight of maize in four treatments in four soils.

The agronomic suitability of the biologically produced PARP as a source of $\mathrm{P}$ in maize based on biomass yield relative to Single Superphosphate recorded above $97 \%$ throughout the four soils (with $97.8 \%$ in Mporokoso soils, $99.5 \%$ in Mufulira soils, $99.6 \%$ in Mansa soils and $100 \%$ in Kasama soils). The calculated RAE based on P uptake was a little lower for all the soils except for Kasama soil with 100\%; (94\% in Mufulira, 85\% in Mansa and 79\% in Mporokoso soils), though an ANOVA on the P uptake mean values showed no significant difference ( $p>0.05$ ) between the PARP and the SSP treatments. Similarly the RAE of GPR ranged between 26\% in Kasama soil to 33\% in Mporokoso soils based on biomass yield while the RAE based on P uptake ranged between 6.9\% in Mporokoso soil to $12 \%$ in Mufulira both indicating a very low $\mathrm{P}$ uptake effectiveness (see Table 5). 
Table 5. Mean value of plant height, $P$ up taken biomass yield and the RAE \% among sources of P (control, GRP, PARP, and SSP) in the four types soils (same letter in a column were not significantly different at $(\mathrm{p}<0.05))$.

\begin{tabular}{|c|c|c|c|c|c|c|}
\hline \multirow{2}{*}{ Soil } & \multirow{2}{*}{ Treat } & \multirow{2}{*}{$\begin{array}{l}\text { Plant height } \\
\text { (@7 weeks) }\end{array}$} & \multirow{2}{*}{$\begin{array}{c}\text { P uptake } \\
(\%)\end{array}$} & \multirow{2}{*}{$\begin{array}{c}\text { Biomass } \\
\text { yield (g/pot) }\end{array}$} & \multicolumn{2}{|c|}{ RAE \% } \\
\hline & & & & & P uptake & Biomass Yield \\
\hline \multirow{4}{*}{ Mufulira } & Control & $6.4^{\mathrm{a}}$ & $0.04^{\mathrm{c}}$ & $10.38^{\mathrm{c}}$ & & \\
\hline & GRP & $6.7^{\mathrm{a}}$ & $0.08^{\mathrm{b}}$ & $21.57^{b}$ & 12.9 & 33.1 \\
\hline & PARP & $9.0^{\mathrm{b}}$ & $0.33^{\mathrm{a}}$ & $47.67^{\mathrm{a}}$ & 93.5 & 99.5 \\
\hline & SSP & $9.4^{\mathrm{b}}$ & $0.35^{\mathrm{a}}$ & $48.12^{\mathrm{a}}$ & 100.0 & 100 \\
\hline \multirow{4}{*}{ Mansa } & Control & $6.5^{\mathrm{a}}$ & $0.02^{\mathrm{c}}$ & $10.83^{\mathrm{c}}$ & & \\
\hline & GRP & $7.4^{\mathrm{a}}$ & $0.05^{\mathrm{b}}$ & $21.88^{\mathrm{b}}$ & 9.7 & 28.3 \\
\hline & PARP & $9.8^{\mathrm{b}}$ & $0.30^{\mathrm{a}}$ & $47.77^{\mathrm{a}}$ & 84.8 & 99.6 \\
\hline & SSP & $10.0^{\mathrm{b}}$ & $0.35^{\mathrm{a}}$ & $49.08^{\mathrm{a}}$ & 100.0 & 100 \\
\hline \multirow{4}{*}{ Kasama } & Control & $6.8^{\mathrm{a}}$ & $0.03^{c}$ & $10.32^{c}$ & & \\
\hline & GRP & $7.6^{\mathrm{a}}$ & $0.07^{\mathrm{b}}$ & $24.50^{\mathrm{b}}$ & 10.8 & 25.8 \\
\hline & PARP & $11.0^{\mathrm{b}}$ & $0.40^{\mathrm{a}}$ & $48.67^{\mathrm{a}}$ & 100.0 & 100 \\
\hline & SSP & $11.1 \mathrm{~b}$ & $0.40 \mathrm{a}$ & $48.92^{\mathrm{a}}$ & 100.0 & 100 \\
\hline \multirow{4}{*}{ Mporokoso } & Control & $6.5^{\mathrm{a}}$ & $0.04^{\mathrm{c}}$ & $10.20^{c}$ & & \\
\hline & GRP & $6.9^{\mathrm{a}}$ & $0.06^{\mathrm{b}}$ & $22.75^{\mathrm{b}}$ & 6.9 & 28.1 \\
\hline & PARP & $10.2^{\mathrm{b}}$ & $0.28^{\mathrm{a}}$ & $48.88^{\mathrm{a}}$ & 78.8 & 97.8 \\
\hline & SSP & $10.4^{\mathrm{b}}$ & $0.33^{\mathrm{a}}$ & $49.12^{\mathrm{a}}$ & 100.0 & 100 \\
\hline
\end{tabular}

\section{Discussion}

\subsection{Comparison of P Uptake by the Maize among Soil Treatments}

The control in all the four soils from the different districts had the lowest percentage of phosphorous in the above ground dry matter weight. It is not surprising that the lowest level of percentage phosphorous were observed in the control treatments since the soils used in this study were strongly acidic on average of $<4.5 \mathrm{pH}$ (Table 3) with P ranging from $2-3 \mathrm{ppm}$. Similarly, in the GRP the $\mathrm{P}$ uptake was slightly increased because of ground rock phosphate (GRP) application. However, the GPR is known for its slow P release when applied directly to the soil as a fertilizer. In this study it was observed that $\mathrm{P}$ uptake was only $0.06 \%-0.08 \% \mathrm{P} /$ pot in GRP compared to the $0.33 \%-0.40 \% \mathrm{P}$ in the PARP and SSP. This low concentration of $\mathrm{P}$ in GRP treatment limited the P uptake and growth of these potted plants because of its relative insolubility [24]. Mapiki and Singh [1] also found that direct application of Chilembwe PR to all the test crops was generally ineffective as a $\mathrm{P}$ source. In addition, the soil $\mathrm{pH}$ of $<4.5$ in the soils was equally low to cause aluminium toxicity. $\mathrm{Al}$ toxicity is usually characterised by an inhibition of $\mathrm{P}$ uptake and translocation with the immobilisation of $\mathrm{P}$ on and in plant roots [25]. Large concentrations of $\mathrm{Al}$ can severely restrict root 
system development with the associated consequences on soil exploration and $\mathrm{P}$ uptake. Plants growing under acidic conditions can therefore exhibit both a stunted root system due to $\mathrm{Al}$ toxicity and $\mathrm{P}$ deficiency. Soil solution and labile $\mathrm{P}$ have both been shown to reach a minimum value at $\mathrm{pH} 5.5$ [26]. However, the $\mathrm{P}$ uptake in the PARP and SSP treatments were significantly higher $(\mathrm{p}<0.05)$ than the control and the GRP treatments in spite of the above soil acidic conditions. The P uptake from PARP and SSP treatments with readily available phosphorus in soils were not significantly different $(\mathrm{p}<0.05)$. The two treatments had the highest levels of $\mathrm{P}$ uptake across the four soils in spite of the low $\mathrm{pH}$ and their associated potential $\mathrm{Al}$ and $\mathrm{Mn}$ toxicities and $\mathrm{P}$ deficiency. The negative effect of soil acidity could have been overcome by the large concentration of $\mathrm{P}$ provided by its dissolution of the two fertilizers. It has been observed that maintaining an adequate soil P status reduces the effects of soil acidity on plant growth [25] [27] by its liming effect [25]. From the results the PARP was an effective fertilizer comparable to SSP in providing $\mathrm{P}$ for the growth of the plant regardless of the soil type. This result can be explained by the fact that these two fertilizers provided prompt release of phosphorus, making it more available to the plants. The higher concentration of $\mathrm{P}$ in the plant was attributed to a higher $\mathrm{P}$ content in the soil provided by the PARP and the SSP fertilizers. Phosphorus solubilizing bacteria play role in phosphorus nutrition by enhancing its availability to plants through release of $P$ from the PR by solubilization and mineralization [28] [29]. PAPRs may offer an economic means [3] of enhancing the agronomic effectiveness of indigenous PR sources that may otherwise be unsuited for direct application.

\subsection{Comparison of Above Ground Biomass Yield of Maize among Soil Treatments}

Similarly, the biomass yield (47.7 - $49.1 \mathrm{~g} /$ pot range) in PARP and SSP treatments followed a similar trend in all the four soils from the different districts, however, the soil with GRP (21.6 - $24.3 \mathrm{~g} /$ pot range) was significantly different ( $\mathrm{p}<0.05)$ from the control $(10.2-10.9 \mathrm{~g} /$ pot range) as shown in Table 5 and Figure 2(b). This shows that grinding rock phosphate and mixing it to the soil will enhance crop growth but not as effective as water soluble P fertilizer like the SSP or the PARP because of its slow dissolution and does not promptly release phosphorus, for plant growth and biomass yield. On the other hand, the PARP has been observed to be as effective as water soluble P fertilizer (the SSP) through many studies conducted internationally [30]. The soluble $\mathrm{P}$ fractions in these two fertilizers stimulated root growth and facilitated greater exploitation of $\mathrm{P}$ enriched soil thereby producing higher amounts of plant biomass. The soils in the Control and the GRP were heavily affected by the low $\mathrm{pH}(<4.1)$ at which $\mathrm{Al}$ and Mn toxicity (pH 5.5 is the threshold for soil acidity [25] [31] is prevalent and phosphorus fixation eminent, creating detrimental conditions for crop growth hence the observed low biomass yields in the two treatments. The fact that there 
was no significant difference among the soils with regard to biomass yield shows that the soils did not have other underlying factors that seriously negatively affect the plant growth other than the $\mathrm{P}$ availability.

\subsection{The Agronomic Effectiveness of the GRP and PARP}

The agronomic effectiveness of GRP and PARP were measured relative to SSP (a water soluble $\mathrm{P}$ fertilizer), referred to as Relative Agronomic Effectiveness (RAE). The RAE values for GRP and PARP were calculated from the ratio of the marginal increase in Biomass yield or $\mathrm{P}$ uptake from the $\mathrm{P}$ sources in comparison to SSP (Table 5). The RAE based on biomass was higher than the one based on $P$ uptake in both GRP and PARP phosphorus sources. The RAE of GRP based on biomass ranged from $25.5 \%$ in Kasama soil to $28.8 \%$ in Mufulira compared to 6.9\% in Mporokoso soil to $12.9 \%$ in Mufulira soils while that of PARP ranged from $97.8 \%$ in Mporkoso soil to $100 \%$ in Kasama soil compared to $78.9 \%$ in Mprorokoso soils to $100 \%$ in Kasama soil. Despite the fact that the RAE values based on biomass yield were in most cases higher than those base on the P uptake, the trend was the same. However, the $\mathrm{P}$ uptake may be a more sensitive indicator of relative agronomic performance of $\mathrm{P}$ sources than biomass yield because $\mathrm{P}$ uptake reflects the differences in internal efficiency of $\mathrm{P}$ supplied to plant by different $\mathrm{P}$ sources [32] [33] also reported that phosphorus-uptake (acquisition) efficiency resulted in higher yield increase as compared to internal P-utilization efficiency in rice [34]. Based on P uptake, the application of PARP was $100 \%$ as effective as SSP in Kasama soil, $94 \%$ in Mufulira soils, $85 \%$ in Mansa soil and $79 \%$ in Mporokoso soil with an average of $90 \%$ effectiveness. Similiarly, Khau et al. (2009) [29] also found out that the use of phosphorus solubilizing bacteria on PR increased P uptake. This indicates that PARP is a reactive phosphate rock form that is suitable for direct application and its outstanding performance at all sites is consistent with the available $\mathrm{P}$ provided by its application. According to FAO [30] and Chien [35], PAPRs may offer an economic means of enhancing the agronomic effectiveness of indigenous PR sources that may otherwise be unsuited for direct application as the PAPRs are cheaper than fully acidulated Water Soluble Phosphates fertilizers because less acid and energy is required per unit of $\mathrm{P}$ in its production.

\section{Conclusion}

This study shows the importance of the local rock phosphate as a source of phosphorus in maize plant in acidic soils. The biologically produced PARP significantly $(\mathrm{p}<0.01)$ enhanced both $\mathrm{P}$ uptake and biomass yield of maize compared to the control and the GRP. The GRP is slow in dissolving and does not promptly release phosphorus, for plant uptake, growth and biomass yield and therefore not suitable for direct application. The relative agronomic effectiveness of PARP in relation to SSP based on P uptake and biomass yield was $>90 \%$ suggesting that PARP is as good as SSP fertilizer and therefore a suitable alternative 
source of $\mathrm{P}$ for direct application in the soil for crop production. In addition, PAPRs may offer an economic means of enhancing the agronomic effectiveness of indigenous PR sources of $\mathrm{P}$.

\section{Acknowledgements}

This work was supported by the Agricultural Productivity Programme for southern Africa (APPSA) through Zambia Agriculture Research Institutes.

Authors thank Mr Boyd Zimba for his assistance in the management of the experiment, data collection, and chemical analysis of the plant and soil samples. The authors are also grateful to the ZARI and UNZA for providing the greenhouse and laboratory facilities.

\section{Conflicts of Interest}

The authors declare no conflicts of interest regarding the publication of this paper.

\section{References}

[1] Mapiki, A. and Singh, B.R. (1990) Agronomic Potential of Indigenous Phosphate Rocks as a Phosphorus Fertilizer in Zambia. (Interim Report) Norwegian Centre for International Agricultural Development, Agricultural University of Norway, As, Norway.

[2] Guldberg, M. (1958) Phosphorous Sorption in Some Acid Zambian Soils. M.Sc. Thesis, Dept. of Soil and Water Sciences, Agricultural University of Norway, As, Norrway.

[3] Cicek, H., Bhullar, G.S., Mandloi, L.S., Andres, C. and Riar, A.S. (2020) Partial Acidulation of Rock Phosphate for Increased Productivity in Organic and Smallholder Farming. Sustainability, 12, 607. https://doi.org/10.3390/su12020607

[4] Palm, C.A., Myers, R.J.K. and Nandwa, S.M. (1997) Combined Use of Organic and Inorganic Nutrient Sources for Soil Fertility Maintenance and Replenishment. In: Buresh, R.J., et al., Eds., Replenishing Soil Fertility in Africa, SSA Special Publ. 51, SSA, Madison, 193-217. https://doi.org/10.2136/sssaspecpub51.c8

[5] Mweetwa, A.M., Eckhardt, E.A., Stott, D.E., Chilombo, G., Armstrong, A.P., Schulze, D. and Nakatsu, C.H. (2014) Isolation and Characterization of Chilembwe and Sinda Rock Phosphate Solubilizing Soil Microorganisms. African Journal of Microbiology Research, 8, 3191-3203. https://doi.org/10.5897/AJMR2014.6923

[6] MINEX (1986) Report on Phosphate Rock Reserves in Zambia and Their Potential for Mining.

[7] MAFF (1995) Production and Marketing Potential of Rock Phosphate in Zambia.

[8] Appleton, J.D. (2001) Local Phosphate Resources for Sustainable Development in Sub-Saharan Africa. National Environment Research Council, British Geological Survey and DFID, Keyworth.

[9] Sliwa, A.S. (1991) Phosphate Resources of Zambia and Progress in Their Exploration. Fertilizer Research, 30, 203-212. https://doi.org/10.1007/BF01048655

[10] van Straaten, P. (2002) Rocks for Crops: Agrominerals of Sub-Saharan Africa. ICRAF, Nairobi, 338 p. 
[11] Mulela, D. (1991) Igneous Phosphate Occurrences in Zambia. In: Zambia Fertilizer Technology Development Committee (ZFTDC) Utilization of Local Phosphate Deposits for the Benefits of the Zambian Farmer, Technische Universiteit Delft, Delft, NL, 15-25.

[12] Phiri, S., Mapiki, A., Goma, H.C. and Singh, B.R. (1993) Agronomic Evaluation of Partially Acidulated Phosphate Rock in Northern Zambia. In: The Zambia Fertilizer Technology Development Committee-ZFTDC: Proceedings of an International Workshop: Phosphate Rock-Derivates and Their Use, Technische Universiteit Delft, Delft, NL, 41-48.

[13] Sinclair, A.G. and Dyson, C.B. (1988) An Interim Report on the MAF (National Series) Forms of Fertilizer Trials, Wellington.

[14] Simukanga, S., Nkonde, G.K. and Shitumbanuma, V. (1994) Status of Phosphate Rock in Zambia-Resources and Use. In: Mathers, S.J. and Notholt, A.J.G., Eds., Industrial Minerals in Developing Countries, AGID Report Series Geosciences in International Development, Vol. 18, AGID, Nottingham, 257-264.

[15] Hellal, F., El-Sayed, S., Zewainy, R., et al. (2019) Importance of Phosphate Pock Application for Sustaining Agricultural Production in Egypt. Bulletin of the National Research Centre, 43, 11. https://doi.org/10.1186/s42269-019-0050-9

[16] Avdalovic, J., Beškoski, V., Gojgic-Cvijovic, G., Mattinen, M., Stojanovic, M., Zildžovic, S. and Vrvic, M.M. (2015) Microbial Solubilization of Phosphorus from Phosphate Rock by Iron-Oxidizing Acidithiobacillus sp. B2. Minerals Engineering, 72, 17-22. https://doi.org/10.1016/j.mineng.2014.12.010

[17] Xiao, C., Wang, Q., Feng, B., Xu, G. and Chi, R. (2018) Biosolubilization of Rock Phosphates in a Bioreactor Using a Microbial Consortium from Rhizospheric Soils: An Analysis of the Microbial Community and Technical Feasibility. Mining, Metallurgy \& Exploration, 35, 184-191. https://doi.org/10.19150/mmp.8595

[18] Leathen, W.W., Kinsel, N.A. and Braley, S.A. (1956) Ferrobacillus Ferrooxidans: A Chemosynthetic Autotrophic Bacterium. Journal of Bacteriology, 72, 700-704. https://doi.org/10.1128/JB.72.5.700-704.1956

[19] Silverman, M.P. and Lundgreen, D.G. (1959) Studies on the Chemoautotrophic Iron Bacterium Ferrobacillus Ferrooxidans: An Improved Medium and Harvesting Procedure for Securing High Cell Yields. Journal of Bacteriology, 77, 642-647. https://doi.org/10.1128/JB.77.5.642-647.1959

[20] Leathen, W.W., Mcintyre, L.D. and Braley, S.A. (1951) A Medium for the Study of the Bacterial Oxidation of Ferrous Iron. Science, 114, 280-281.

https://doi.org/10.1126/science.114.2959.280

[21] Leathen, W.W., Kinsel, N.A. and Braley, S.A. (1955) A Solid Medium for the Study of Ferrobacillus Ferrooxidans. Bacteriology Proceedings, 46. https://jb.asm.org/content/jb/72/5/700.full.pdf

[22] Ghani, A., et al. (1994) Enhancement of Phosphate Rock Solubility through Biological Processes. Soil Biology and Biochemistry, 26, 127-136.

https://doi.org/10.1016/0038-0717(94)90204-6

[23] Van Ranst, E., Verloo, M., Demeyer, A. and Pauwels, J.M. (1999) Manual for the Soil Chemistry and Fertility Laboratory-Analytical Methods for Soils and Plants, Equipment, and Management of Consumables. NUGI 835, Ghent, 243 p.

[24] Nyambati, R.O. and Opala, P.A. (2014) The Effect of Minjingu Phosphate Rock and Triple Superphosphate on Soil Phosphorus Fractions and Maize Yield in Western Kenya. International Scholarly Research Notices, 2014, Article ID: 920541. 
https://doi.org/10.1155/2014/920541

[25] Edwards, A.C. (1991) Soil Acidity and Its Interactions with Phosphorus Vailability for a Range of Different Crop Types. In: Plant-Soil Interactions at Low pH, Springer, Berlin, Volume 45, 299-305. https://doi.org/10.1007/978-94-011-3438-5_33

[26] Murrman, R.P. and Peach, M. (1969) Effect of Soil pH on Labile and Soluble Phosphate in Soils. Soil Science Society of America, Proceedings, 33, 205-210. https://doi.org/10.2136/sssaj1969.03615995003300020015x

[27] Sinclair, A.H. and Edwards, A.C. (1986) Soil Activity and Its Interaction with Phosphorus and Micronutrients. Macaulay Institute Technical Note No. 7.

[28] Girmay, K. (2019) Phosphate Solubilizing Microorganisms: Promising Approach as Biofertilizers. International Journal of Agronomy, 2019, Article ID: 4917256. https://doi.org/10.1155/2019/4917256

[29] Khau, A.A., Jilani, G., Salam, M., Akhatar, S.M., Saqlan, N. and Mohammad, R. (2009) Phosphorus Solubilizing Bacteria Occurrences Microorganisms and Their Role in Crop Production. Journal of Agricultural and Biological Sciences, 1, 48-58.

[30] FAO (2004) Use of Phosphate Rocks for Sustainable Agriculture. FAO Fertilizer and Plant Nutrition Bulletin No. 13, Rome.

[31] Cerozi da Silva, B. and Fitzsimmons, K. (2016) The Effect of pH on Phosphorus Availability and Speciation in an Aquaponics Nutrient Solution. Bioresource Technology, 219, 778-781. https://doi.org/10.1016/j.biortech.2016.08.079

[32] Dodor, D.E. (2016) Relative Agronomic Effectiveness of Some African Rock Phosphate Fertilizers in an Ultisol of Okinawa, Japan. West African Journal of Applied Ecology, 24, 45-55.

[33] Vandamme, E., Rose, T.J., Saito, K., Jeong, K. and Wissuwa, M. (2016) Integration of P Acquisition Efficiency, P Utilization Efficiency and Low Grain P Concentration into P Efficient Rice Genotypes for Specific Target Environments. Nutrient Cycling in Agroecosystems, 104, 413-427. https://doi.org/10.1007/s10705-015-9716-3

[34] Gemenet, D.C., Leiser, W.L., Beggi, F., Herrmann, L.H., Vadez, V., Rattunde, H.F., Weltzien, E., Hash, C.T., Buerkert, A. and Haussmann, B.I. (2016) Overcoming Phosphorus Deficiency in West African Pearl Millet and Sorghum Production Systems: Promising Options for Crop Improvement. Frontiers in Plant Science, 7, 1389. https://doi.org/10.3389/fpls.2016.01389

[35] Chien, S.H. (2003) IFDC's Evaluation of Modified Phosphate Rock Products. In: Rajan, S.S.S. and Chien, S.H., Eds., Direct Application of Phosphate Rock and Related Technology: Latest Developments and Practical Experiences. Proc Int. Meeting, Kuala Lumpur, 16-20 July 2001, Muscle Shoals, USA, IFDC, 441 p. 